University of Nebraska - Lincoln

DigitalCommons@University of Nebraska - Lincoln

PITUITARY-TESTICULAR RESPONSES OF ESTRADIOL-17 $\beta$ IMPLANTED BULL CALVES TO CONTINUOUS VERSUS PULSATILE INFUSION OF LUTEINIZING HORMONE RELEASING HORMONE

Bruce D. Schanbacher

USDA-ARS

Follow this and additional works at: https://digitalcommons.unl.edu/usdaarsfacpub

Part of the Agricultural Science Commons

Schanbacher, Bruce D., "PITUITARY-TESTICULAR RESPONSES OF ESTRADIOL-17 $\beta$-IMPLANTED BULL CALVES TO CONTINUOUS VERSUS PULSATILE INFUSION OF LUTEINIZING HORMONE RELEASING HORMONE" (1984). Publications from USDA-ARS / UNL Faculty. 770.

https://digitalcommons.unl.edu/usdaarsfacpub/770

This Article is brought to you for free and open access by the U.S. Department of Agriculture: Agricultural Research Service, Lincoln, Nebraska at DigitalCommons@University of Nebraska - Lincoln. It has been accepted for inclusion in Publications from USDA-ARS / UNL Faculty by an authorized administrator of DigitalCommons@University of Nebraska - Lincoln. 


\title{
PITUITARY-TESTICULAR RESPONSES OF ESTRADIOL-17 $\beta$-IMPLANTED BULL CALVES TO CONTINUOUS VERSUS PULSATILE INFUSION OF LUTEINIZING HORMONE RELEASING HORMONE ${ }^{1}$
}

\author{
Bruce D. Schanbacher \\ US Department of Agriculture 2,3 , \\ Clay Center, NE 68933
}

\begin{abstract}
Summary
The luteinizing hormone (LH), folliclestimulating hormone (FSH) and testosterone response of bull calves implanted with estradiol$17 \beta$ to continuous and pulsatile infusion of luteinizing hormone releasing hormone (LHRH) has been examined. Estradiol- $17 \beta$ reduced serum LH and FSH concentrations and suppressed testosterone secretion and testicular growth when compared with sham-implanted bulls. Pulsatile iv infusion of LHRH [500 ng every $2 \mathrm{~h}$ $(6 \mu \mathrm{g} / \mathrm{d})]$ for a 4 -wk period to estradiol-17 $\beta$ implanted bulls resulted in elevated mean serum $\mathrm{LH}$ and testosterone concentrations that were characterized by discrete secretory episodes. Mean serum FSH was also increased by LHRH pulse infusion, but LHRH-coupled secretory episodes were not apparent. Continuous infusion of LHRH $(6 \mu \mathrm{g} / \mathrm{d})$ did not increase the low serum gonadotropin levels observed in estradiol$17 \beta$-implanted calves. Testicular growth was normal in LHRH pulse-infused calves, but was
\end{abstract}

\footnotetext{
${ }^{1}$ The author acknowledges the technical assistance of Kathy Sorenson, Cindy Rainbolt and Debbie Brown and the cooperation of the Univ. of Nebraska and the Nebraska Agr. Exp. Sta. Acknowledgement is also extended to Dr. D. J. Bolt, USDA, ARS, Beltsville, $M D$, for $L H$ antiserum (DJB 3-12/11); Dr. K. W. Cheng, Univ. of Manitoba (Winnipeg), for FSH antiserum, Dr. P. N. Rao, Southwest Foundation for Research and Education, San Antonio, TX, for testosterone antiserum $(X-181)$ and the Endocrine Study Section, National Institutes of Health, Bethesda, MD, for the bovine reference standards (NIH-LH-B10 and NIH-FSH-B 1).

${ }^{2}$ Roman L. Hruska U.S. Meat Animal Research Center, ARS.

${ }^{3}$ Mention of trade names or companies does not constitute an implied warranty or endorsement by the author or USDA.

Received July 18, 1983.

Accepted September 30, 1983.
}

markedly curtailed in continuously infused calves. These results suggest that estradiol-17 $\beta$ inhibits testicular development by blocking gonadotropin release at the level of the hypothalamus because pulsatile administration of LHRH can override the inhibitory effect by increasing $\mathrm{LH}$ and FSH secretion.

(Key Words: Luteinizing Hormone Releasing Hormone, Luteinizing Hormone, FollicleStimulating Hormone, Testosterone, Testes, Bulls.)

\section{Introduction}

The onset of sexual maturation (puberty) in the male bovine is poorly understood. While numerous investigators have failed to reveal age-related changes in gonadotropin secretion (MacMillan and Hafs, 1968; Karg et al., 1976; Schanbacher, 1979a), others have identified a changing pattern of pituitary gonadotropin release (Rawlings et al., 1972; Lacroix et al., 1977; Lacroix and Pelletier, 1979a) and have emphasized the physiological importance of an episodic secretory pattern for activation of testicular function near the time of puberty (Schanbacher, 1981; Schanbacher et al., 1982). To further investigate the neuroendocrine mechanism(s) that governs pubertal development in the bull, the bull calf implanted with estradiol $-17 \beta$ has been chosen as a model for study. The efficacy by which estradiol- $17 \beta$ inhibits the hypothalamic luteinizing hormone releasing hormone (LHRH) pulse generator, and thereby blocks pulsatile gonadotropin secretion and testicular development in young bulls, makes this model particularly useful (Schanbacher, 1981). Recently, we reported that hourly pulsatile LHRH administration overrides the inhibitory effects of estradiol $-17 \beta$ on testicular development in calves by providing an episodic mode of luteiniżing hormone (LH) 943

JOURNAL OF ANIMAL SCIENCE, Vol. 58, No. 4, 1984 
stimulation to the testes (Schanbacher et al., 1982). While the effect of increased LH output may have been paramount to these results, our interpretations may have been premature or unjustified without information pertaining to the secretion of follicle-stimulating hormone (FSH). The following study was conducted to determine the relative importance of continuous vs pulsatile infusion of the hypothalamic releasing hormone, LHRH, on testicular development of implanted bulls and to assess the effects of the estradiol-17 $\beta$ and LHRH treatments on FSH secretion.

\section{Materials and Methods}

Twelve spring-born Hereford bull calves weighing $186 \pm 2 \mathrm{~kg}$ were weaned at $26 \mathrm{wk}$ of age and assigned randomly to one of four experimental groups. Animals in group 1 served as sham-implanted controls while the animals in the three remaining groups were implanted at 33 wk of age with a Silastic ${ }^{4}$ capsule containing crystalline estradiol-17 $\beta^{5}$ as described earlier (Schanbacher, 1981). Although group 2 animals received no further treatment, the six animals in group 3 and 4 were administered $6 \mu \mathrm{g}$ of LHRH/d via either continuous (group 3 ) or pulsatile (group 4) iv infusion. Calves were placed in individual stalls for the duration of the study and equipped with tridodecylmethylammonium chloride (TDMAC)-heparinized, infusion and withdrawal jugular cannulae ${ }^{6}$ as described previously (Schanbacher et al., 1982) for this purpose.

Infusions commenced immediately after a 5 -h blood collection period at 34 wk of age (i.e., $3 \mathrm{~d}$ after being implanted with the estradiol$17 \beta$ capsule). Additional blood samples were taken at 15-min intervals for $5 \mathrm{~h}$ from each of the 12 calves after $1,2,3$ and 4 wk of treatment (i.e., 35, 36, 37 and 38 wk of age). Serum was harvested from all samples, frozen and subsequently assayed for LH and FSH (Schanbacher, $1979 \mathrm{~b})$. Testosterone concentrations were determined in all samples by double-antibody radioimmunoassay (Schanbacher and D'Occhio, 1982), whereas estradiol-17 $\beta$ concentrations were determined in weekly serum pools for

\footnotetext{
${ }^{4}$ Dow Corning, Midland, MI.

${ }^{5}$ Sigma Chemical Co., St. Louis, MO. $\mathrm{OH}$.

${ }^{6}$ Tygon Microbore Tubing; Norton Plastics, Akron,
}

each of the 12 calves (D'Occhio et al., 1982). Changes in testicular size were determined by measuring testis diameters for each calf with calipers at the time of implanting and at 34,35 , 36,37 and 38 wk of age.

Means of the weekly hormonal profiles were subjected to split-plot in time analysis of variance with treatment groups representing main effects and time (wk) providing the subplot (Steel and Torrie, 1960).

\section{Results}

Mean serum $\mathrm{LH}$ and testosterone concentrations were significantly suppressed $(\mathrm{P}<.01)$ in estradiol-17 $\beta$-supplemented calves within $3 \mathrm{~d}$ of treatment (figure 1, table 1). Serum FSH tended to be lower in the estradiol-implanted calves at this time; however, the decrease was not significant.

The effects of the main treatments, estradiol$17 \beta$ supplementation and LHRH infusion, were particularly pronounced. The nonimplanted, control calves maintained normal serum concentrations of LH, FSH and testosterone throughout the 4-wk study, whereas estradiol$17 \beta$-implanted calves maintained significantly reduced $(P<.01)$ serum concentrations of all three hormones. Continuous infusion of LHRH into estradiol-17 $\beta$-implanted calves (group 3 ) was without effect [i.e., serum concentrations of LH, FSH and testosterone remained low and similar to the concentrations observed in noninfused, estradiol-17 $\beta$-implanted calves (group 2)]. In contrast, estradiol-17 $\beta$-implanted calves pulsed with LHRH (group 4) had markedly increased $(P<.01)$ serum concentrations of $\mathrm{LH}, \mathrm{FSH}$ and testosterone during the 4 wk of treatment when compared with the two other groups of calves implanted with estradiol- $17 \beta$. Compared with nonimplanted, control calves, estradiol-17 $\beta$-implanted calves pulsed with LHRH had similar LH concentrations, but significantly elevated serum concentrations of FSH $(\mathrm{P}<.05)$ and testosterone $(\mathrm{P}<.01)$. Fivehour profiles of $\mathrm{LH}$ and testosterone from wk 0,2 and 4 are shown for each of the four groups of calves in figure 1 . The episodic nature of $\mathrm{LH}$ and testosterone release in control bulls is reflected by their erratic mean profiles and can be easily contrasted with the synchronous pulsatile profiles of estradiol-17 $\beta$-implanted calves infused with $500 \mathrm{ng}$ of LHRH every other hour. The FSH profiles were nonpulsatile as interpreted by pulse cycle analysis, and thus are not graphically depicted. 


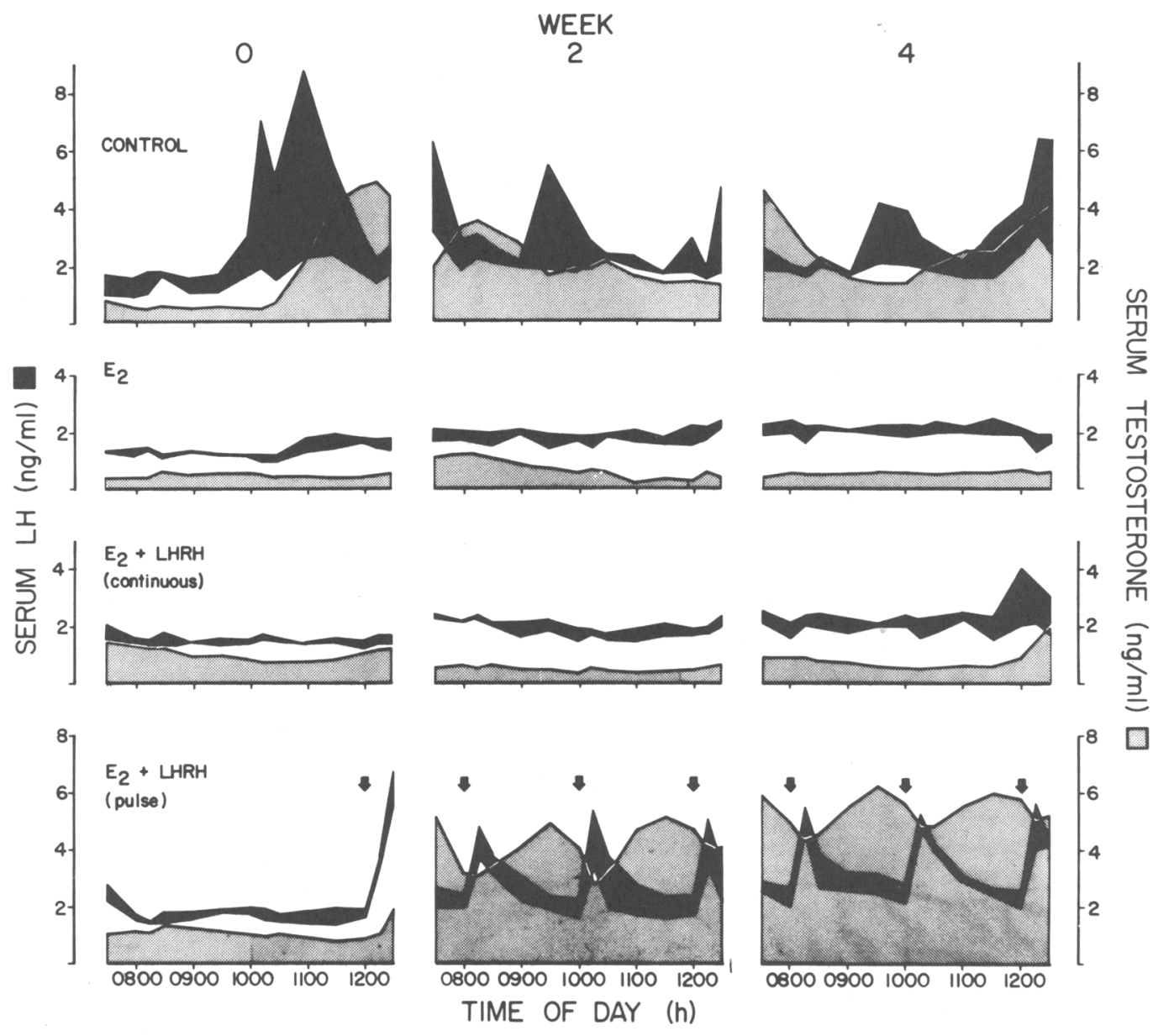

Figure 1. Serum LH and testosterone profiles at 34 (wk 0), 36 (wk 2) and 38 (wk 4) wk of age for three bull calves (controls) and nine bull calves implanted with estradiol-17 $\left(E_{2}\right)$ and given iv infusions of $.9 \% \mathrm{NaCl}\left(\mathrm{E}_{2}\right.$ calves) or luteinizing hormone releasing hormone $(L H R H)$ via continuous $\left(E_{2}+\right.$ LHRH continuous calves) or pulsatile infusion ( $\mathrm{E}_{2}+\mathrm{LHRH}$ pulse calves). The LHRH-infused calves received $6 \mu \mathrm{g}$ of $\mathrm{LHRH} / \mathrm{d}$; either $250 \mathrm{ng} / \mathrm{h}$ continuously or $500 \mathrm{ng}$ via a 30 -s pulse every other hour. Each solid profile presents the mean $\pm \mathrm{SE}$ for serum LH of three calves, whereas the shaded area presents the mean concentrations for serum testosterone $(n=3)$.

The mean concentrations of LH, FSH and testosterone for wk 1,2,3 and 4 often differed within treatment group (table 1); however, no particular trends were evident.

Control and estradiol-17 $\beta$-implanted calves pulsed with LHRH showed a linear increase in testis diameter during the $4 \mathrm{wk}$ of treatment (figure 2). In contrast, estradiol-17 $\beta$-implanted calves and those implanted calves infused with LHRH continuously had suppressed testicular growth.

\section{Discussion}

The results of this and previous studies (Schanbacher, 1981; Schanbacher et al., 1983) provide conclusive evidence that estradiol is a potent inhibitor of gonadotropin secretion in the young male bovine. The absence of detectable episodic $\mathrm{LH}$ release and resultant low serum testosterone concentrations in estradiol$17 \beta$-supplemented calves indicate that an active LHRH pulse generator in the hyopthalamus is essential for testicular growth and normal sexual development at the time of puberty (Lacroix and Pelletier, 1979b). The inhibitory effects of estradiol-17 $\beta$ on testicular function can be overcome if LHRH is administered in a pulsatile fashion. The success of hourly pulsatile LHRH infusion (Schanbacher et al., 1982) was paralleled in the present study by administering the same dose $(500 \mathrm{ng})$ only once ever $2 \mathrm{~h}$. 
TABLE 1. MEAN SERUM CONCENTRATIONS OF LH, FSH AND TESTOSTERONE IN THREE BULL CALVES (CONTROLS) AND NINE BULL CALVES IMPLANTED WITH ESTRADIOL-17 $\beta\left(E_{2}\right)$ AND GIVEN INTRAVENOUS INFUSION OF .9\% NaCl $\left(W / V ; E_{2}\right.$ CALVES) OR LUTEINIZING HORMONE RELEASING HORMONE (LHRH) VIA CONTINUOUS INFUSION ( $E_{2}+$ LHRH CONTINUOUS CALVES) OR PULSATILE INFUSION $\left(E_{2}+\text { LHRH PULSE CALVES }\right)^{2}$

\begin{tabular}{|c|c|c|c|c|}
\hline $\begin{array}{l}\text { Treatment } \\
\text { group }\end{array}$ & Week & LH & FSH & Testosterone \\
\hline Control & $\begin{array}{l}0 \\
1 \\
2 \\
3 \\
4\end{array}$ & $\begin{array}{l}2.47 \pm .36 \mathrm{~b} \\
2.26 \pm .20^{\mathrm{b}} \\
2.56 \pm .22^{\mathrm{b}} \\
3.33 \pm .26^{\mathrm{c}} \\
2.60 \pm .25^{\mathrm{b}}\end{array}$ & $\begin{array}{l}119 \pm 8^{b} \\
126 \pm 7^{b} \\
145 \pm 11^{b} \\
130 \pm 8^{b} \\
136 \pm 9^{b}\end{array}$ & $\begin{array}{l}1.81 \pm .48^{\mathrm{b}} \\
1.95 \pm .30^{\mathrm{b}} \\
1.88 \pm .21^{\mathrm{b}} \\
3.20 \pm .30^{\mathrm{c}} \\
2.57 \pm .28^{\mathrm{bc}}\end{array}$ \\
\hline$E_{2}$ & $\begin{array}{l}0 \\
1 \\
2 \\
3 \\
4\end{array}$ & $\begin{array}{l}1.36 \pm .06^{b} \\
1.60 \pm .05^{b c} \\
1.90 \pm .08^{c} \\
1.53 \pm .13^{b c} \\
1.99 \pm .04 c\end{array}$ & $\begin{array}{l}85 \pm 11 b \\
88 \pm 5 b \\
85 \pm 7 b \\
85 \pm 9 b \\
89 \pm 8 b\end{array}$ & $\begin{array}{l}.55 \pm .02^{b} \\
.37 \pm .04^{c} \\
.55 \pm .07^{b} \\
.59 \pm .04^{b} \\
.53 \pm .03^{b}\end{array}$ \\
\hline $\begin{array}{l}\mathrm{E}_{2}+\mathrm{LHRH} \\
\text { (continuous) }\end{array}$ & $\begin{array}{l}0 \\
1 \\
2 \\
3 \\
4\end{array}$ & $\begin{array}{l}1.48 \pm .03^{b} \\
1.72 \pm .07 c \\
1.89 \pm .06^{c} \\
1.76 \pm .09 c \\
1.95 \pm .10^{c}\end{array}$ & $\begin{aligned} 107 & \pm 8 b \\
89 & \pm 9 b \\
95 & \pm 6 b \\
93 & \pm 4 b \\
96 & \pm .10^{b}\end{aligned}$ & $\begin{array}{l}.96 \pm .08^{b} \\
.59 \pm .09^{c} \\
.45 \pm .03^{c} \\
.54 \pm .10^{c} \\
.72 \pm .11^{c}\end{array}$ \\
\hline $\begin{array}{l}\mathrm{E}_{2}+\mathrm{LHRH} \\
\text { (pulse) }\end{array}$ & $\begin{array}{l}0 \\
1 \\
2 \\
3 \\
4\end{array}$ & $\begin{array}{l}1.83 \pm .13^{\mathrm{b}} \\
2.97 \pm .27^{\mathrm{c}} \\
3.43 \pm .28^{\mathrm{d}} \\
4.10 \pm .40^{\mathrm{d}} \\
3.78 \pm .26^{\mathrm{d}}\end{array}$ & $\begin{array}{l}103 \pm 7 b \\
166 \pm 14 c \\
176 \pm 7^{c} \\
193 \pm 9 c d \\
211 \pm 9 d\end{array}$ & $\begin{array}{r}.95 \pm .08^{b} \\
4.59 \pm .22^{c} \\
4.17 \pm .23^{c} \\
6.32 \pm .40^{d} \\
5.40 \pm .37 d\end{array}$ \\
\hline
\end{tabular}

${ }^{a} \mathrm{Values}( \pm \mathrm{SE})$ at $0,1,2,3$ and 4 wk correspond to $34,35,36,37$ and $38 \mathrm{wk}$ of age for each of three calves. $b, c, d$ Means within treatment group having different superscripts differ $(P<.05)$.

Interestingly, the same total dose administered over a prolonged period of time by continuous infusion was ineffective at enhancing serum hormone concentrations and stimulating testicular growth. This differential response to pulsatile vs continuous infusion of $6 \mu \mathrm{g}$ of LHRH can likely be accounted for by the levels of LHRH achieved in serum of infused calves (B. D. Schanbacher, unpublished data). Pulseinfused calves attain measureable and presumably biologically significant quantities of LHRH in their systemic blood (and thus in pituitary portal blood) immediately after pulse infusion. On the other hand, calves infused continuously with only $6 \mu \mathrm{g}$ of LHRH/d are never exposed to enough releasing hormone to temporarily elevate serum LHRH to levels required by the gonadotrophs for gonadotropin release. The ability of pulsatile LHRH administration to maintain or activate reproductive function has been reported by other investigators (Schanbacher and Lunstra, 1977; Belchetz et al., 1978; Lincoln, 1979b).

Initiation of puberty in the infantile female rhesus monkey (Wilde et al., 1980) and reestablishment of ovarian cyclicity in seasonally anestrous ewes (McNatty et al., 1982) and postpartum anestrous beef cows (Walters et al., 1982) has been successfully achieved by pulsatile administration of LHRH. Thus, intermittent small-dose injections of the hypothalamic releasing hormone stimulates the pituitarygonadal axis of both males and females.

Repeated injections of LHRH (gonadotropin releasing hormone, $\mathrm{GnRH}$ ) are known to stimulate FSH as well as $\mathrm{LH}$ release (Lincoln, 1979a; Walters et al., 1982). The increased serum concentrations of FSH in estradiol-17 $\beta$ implanted calves pulsed with LHRH (group 4), therefore, is not particularly surprising. From 


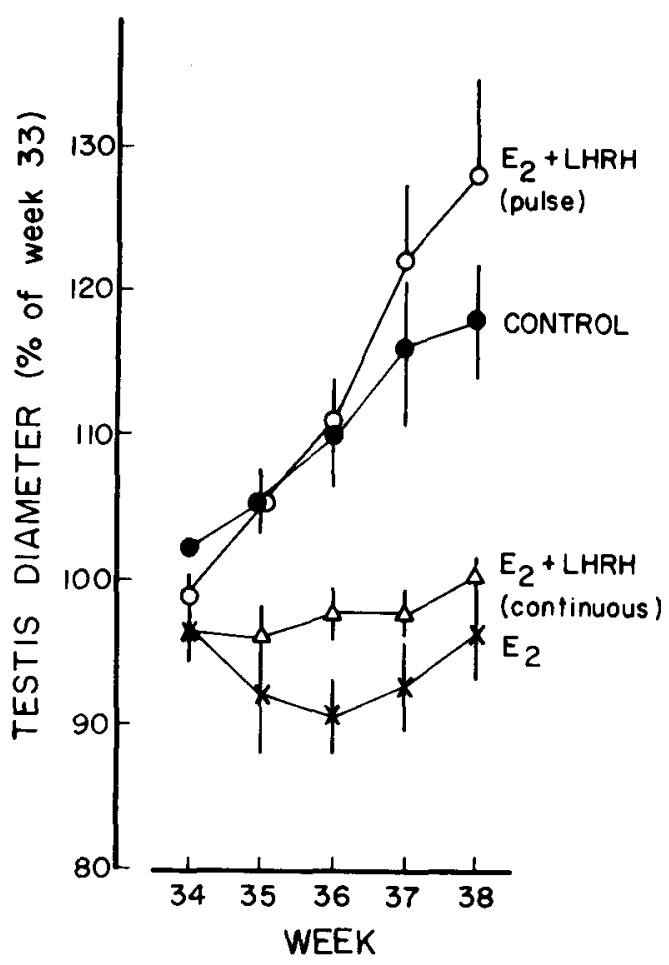

Figure 2. Changes in testis diameter at weekly intervals after estradiol-17 $\left(E_{2}\right)$ treatment and iv infusion of luteinizing hormone releasing hormone (LHRH). LHRH was given either $250 \mathrm{ng} / \mathrm{h}$ continuously or $500 \mathrm{ng}$ via a 30 -s pulse every other hour during the 4-wk study. Mean testis diameter at the time of implanting (wk 33) was 39.5, 38.9, 39.1 and $39.6 \mathrm{~mm}$ for calves in group 1 (controls), $2\left(\mathrm{E}_{2}\right), 3$ $\left(E_{2}+\right.$ LHRH, continuous) and $4\left(E_{2}+\right.$ LHRH, pulse $)$, respectively.

these results, the relative importance of increased LH (testosterone) and FSH cannot be determined. The FSH-dependent nature of testicular function and, in particular, spermatogenesis and Sertoli cell integrity (Amann and Schanbacher, 1983), lead one to conclude that increased FSH may, in part, be responsible for the testicular growth seen in estradiol-17 $\beta$-suppressed calves administered LHRH by pulse infusion.

\section{Literature Cited}

Amann, R. P. and B. D. Schanbacher. 1983. Physiology of male reproduction. J. Anim. Sci. 57 (Suppl. 2): 380 .

Belchetz, P. E., T. M. Plant, Y. Nakai, E. J. Keogh and E. Knobil. 1978. Hypophysial responses to continuous and intermittent delivery of hypothalamic gonadotropin-releasing hormone. Science 202:631.

D'Occhio, M. J., J. E. Kinder and B. D. Schanbacher. 1982. Patterns of $\mathrm{LH}$ secretion in castrated bulls (steers) during intravenous infusion of androgenic and estrogenic steriods: Pituitary response to exogenous luteinizing hormone releasing hormone. Biol. Reprod. 26:249.

Karg, H., T. Giminez, M. Hartl, B. Hoffmann, E. Schallenberger and D. Schams. 1976. Testosterone, luteinizing hormone $(\mathrm{LH})$ and follicle stimulating hormone (FSH) in peripheral plasma of bulls: Levels from birth through puberty and short term variations. Zertralbl. fur Veterinarmedizin Reihe A 23:793.

Lacroix, A., D.-H. Garnier and J. Pelletier. 1977. Temporal fluctuations of plasma LH and testosterone in Charolais bull calves during the first year of life. Ann. Biol. Anim. Biochim. Biophys. 17:1013.

Lacroix, A. and J. Pelletier. 1979a. Short-term variations in plasma $\mathrm{LH}$ and testosterone in bull calves from birth to 1 year of age. J. Reprod. Fertil. $55: 81$.

Lacroix, A. and J. Pelletier. 1979b. LH and testosterone release in developing bulls following LH-RH treatment. Effects of gonadectomy and chronic testosterone propionate pre-treatment. Acta Endocrinol. 91:719.

Lincoln, G. A. 1979a. Differential control of luteinizing hormone and follicle stimulating hormone by luteinizing hormone releasing hormone in the ram. J. Endocrinol. 80:133.

Lincoln, G. A. $1979 \mathrm{~b}$. Use of a pulsed infusion of luteinizing hormone releasing hormone to mimic seasonally induced endocrine changes in the ram. J. Endocrinol. 83:251.

MacMillan, K. L. and H. D. Hafs. 1968. Gonadal and extra gonadal sperm numbers during reproductive development of Holstein bulls. J. Anim. Sci. 27:697.

McNatty, K. P., K. Ball, M. Gibb, N. Hudson and D. C. Thurley. 1982. Induction of cyclic ovarian activity in seasonally anoestrous ewes with exogenous GnRH. J. Reprod. Fertil. 64:93.

Rawlings, N. C., H. D. Hafs and L. V. Swanson. 1972. Testicular and blood plasma androgens in Holstein bulls from birth through puberty. J. Anim. Sci. 34:435.

Schanbacher, B. D. 1979a. Relationship of in vitro gonadotropin binding to bovine testes and the onset of spermatogenesis. J. Anim. Sci. 48:591.

Schanbacher, B. D. $1979 \mathrm{~b}$. Testosterone secretion in cryptochid and intact bulls injected with gonadotropin-releasing hormone and luteinizing hormone. Endocrinology 104:360.

Schanbacher, B. D. 1981. Importance of the episodic nature of luteinizing hormone secretion for normal development of the bovine testis during puberty: Interference with oestradiol-17 $\beta$. J. Endocrinol. 88:393.

Schanbacher, B. D. and. M. J. D'Occhio. 1982. Validation of a direct radioimmunoassay for testosterone in unextracted serum from five species: Application to study of the hypothalamic-pituitarygonadal axis in males. J. Androl. 3:45.

Schanbacher, B. D., M. J. D'Occhio and T. W. Gettys. 1983. Pulsatile luteinizing hormone secretion in the castrate male bovine: Effects of testosterone or estradiol replacement therapy. J. Anim. Sci. 56:132.

Schanbacher, B. D., M. J. D'Occhio and J. E. Kinder. 
1982. Initiation of spermatogenesis and testicular growth in oestradiol-17 $\beta$ implanted bull calves with pulsatile infusion of luteinizing hormone releasing hormone. J. Endocrinol. 93:183.

Schanbacher, B. D. and D. D. Lunstra. 1977. Acute and chronic effects of gonadotropin releasing hormone on reproductive characteristics of rams during the nonbreeding season. J. Anim. Sci. 44:650.

Steel, R.G.D. and J. H. Torrie. 1960. Principles and
Procedures of Statistics. McGraw-Hill Book Co., New York. p 146.

Walters, D. L., C. C. Kaltenbach, T. G. Dunn and R. E. Short. 1982. Pituitary and ovarian function in postpartum beef cows. I. Effect of suckling on serum and follicular fluid hormones and follicular gonadotropin receptors. Biol. Reprod. 26:640.

Wildt, L., G. Marshall and E. Knobil. 1980. Experimental induction of puberty in the infantile female Rhesus monkey. Science 207:1373. 